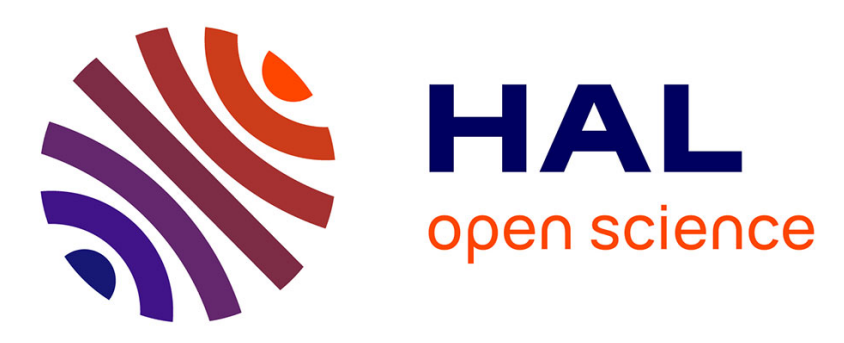

\title{
Influence of Surface Charge and Polymer Coating on Internalization and Biodistribution of Polyethylene Glycol-Modified Iron Oxide Nanoparticles
}

\author{
Lionel Maurizi, Anne-Laure Papa, Laure Dumont, Frédéric Bouyer, Paul
} Walker, David Vandroux, Nadine Millot

\section{To cite this version:}

Lionel Maurizi, Anne-Laure Papa, Laure Dumont, Frédéric Bouyer, Paul Walker, et al.. Influence of Surface Charge and Polymer Coating on Internalization and Biodistribution of Polyethylene GlycolModified Iron Oxide Nanoparticles. Journal of Biomedical Nanotechnology, 2015, 11 (1), pp.126-136. 10.1166/jbn.2015.1996 . hal-02163365

\section{HAL Id: hal-02163365 https://hal.science/hal-02163365}

Submitted on 9 Mar 2021

HAL is a multi-disciplinary open access archive for the deposit and dissemination of scientific research documents, whether they are published or not. The documents may come from teaching and research institutions in France or abroad, or from public or private research centers.
L'archive ouverte pluridisciplinaire $\mathbf{H A L}$, est destinée au dépôt et à la diffusion de documents scientifiques de niveau recherche, publiés ou non, émanant des établissements d'enseignement et de recherche français ou étrangers, des laboratoires publics ou privés. 
Influence of surface charge and polymer coating on internalization and biodistribution of PEG-modified iron oxide nanoparticles

Lionel Maurizi ${ }^{1 \dagger}$, Anne-Laure Papa ${ }^{1 \dagger \dagger}$, Laure Dumont ${ }^{2}$, Frédéric Bouyer ${ }^{1}$, Paul Walker ${ }^{3}$, David Vandroux ${ }^{2}$, and Nadine Millot $^{*}$

${ }^{1}$ Laboratoire Interdisciplinaire Carnot de Bourgogne, UMR 6303 CNRS/Université de Bourgogne, 9 avenue Alain Savary, BP 47870, 21078 Dijon cedex, France

${ }^{2}$ NVH Medicinal, 57 rue Vannerie, 21000 Dijon, France

${ }^{3}$ Departement de Spectroscopie par Résonance Magnétique, Centre Hospitalier Universitaire de Dijon, 2 Boulevard Maréchal de Lattre de Tassigny, 21033 Dijon, France

* Corresponding author: nmillot@u-bourgogne.fr (+333 803 959 37; Fax: +333 803961 67)

$\dagger$ Current address: Powder Technology Laboratory, Ecole Polytechnique Fédérale de Lausanne (EPFL), CH-1015 Lausanne, Switzerland

${ }^{\dagger}$ Current address: Wyss Institute for Biologically Inspired Engineering, Harvard University, Boston, MA 02115, USA 


\begin{abstract}
The aim of this study was to investigate the influence of the surface charge and coating of Superparamagnetic Iron Oxide Nanoparticles (SPIONs) on their in vitro and in vivo behaviors. Neutral and negatively-charged PEG-based SPIONs were synthesized and compared to Resovist ${ }^{\circledR}$, a carboxydextran-based SPION currently used in clinics. Their cytotoxicity, cell internalization, and potential as contrast agents for magnetic resonance imaging were assessed. Neutral pegylated SPIONs were internalized less readily by the reticuloendothelial system and showed a lower uptake by the liver, compared to negativelycharged SPIONs (with carboxydextran and PEG). These results suggested that the charge of functionalized SPIONs was more relevant for their biological interactions than the nature of their coating.
\end{abstract}

Keywords: In vivo assays, Macrophages, MRI (magnetic resonance imaging), Nanoparticles, Surface grafting. 


\section{Introduction}

Superparamagnetic iron oxide nanoparticles (SPIONs) are currently being developed for several biological applications such as hyperthermia, drug delivery ${ }^{1-3}$, or Magnetic Resonance Imaging ${ }^{4-6}$ (MRI). For the latter application, SPIONs are usually used as Water proton transverse relaxation time $\left(\mathrm{T}_{2}\right)$ contrast agents ${ }^{7,8}$, whereas conventional gadolinium chelates $\left(\mathrm{Gd}^{3+}\right)$ are used as $\mathrm{T}_{1}$ contrast agents ${ }^{9}$. However, iron oxide nanoparticles must fulfill certain requirements in order to be used for MRI applications: (i) they should crystallize in a spinel structure $\left(\mathrm{AB}_{2} \mathrm{O}_{4}\right)$ such as $\mathrm{Fe}_{3} \mathrm{O}_{4}$ (magnetite) or $\gamma-\mathrm{Fe}_{2} \mathrm{O}_{3}$ (maghemite) ${ }^{10,11}$ and (ii) their crystallite size should be smaller than $20 \mathrm{~nm}{ }^{12,13}$. The crystallite size of SPIONs also influences their magnetic response in MRI ${ }^{14,15}$.

Moreover, the intrinsic instability of SPIONs in physiological conditions does not allow their use without surface modification. Two types of stabilizing agents are commonly used on the surface of nanoparticles. Electrostatic agents are able to modify the charge of SPIONs in the positive or negative direction. For example, amine ${ }^{16}$, carboxylic acid ${ }^{17}$, or phosphate groups ${ }^{18}$ can be grafted during or after SPION synthesis. They are directly linked to the SPION surface due to the chelating interaction of $\mathrm{OH}$ groups with carboxylic or phosphate groups ${ }^{19,20}$, or by condensation of silane precursors ${ }^{21}$. Alternatively, steric agents stabilize the nanoparticles by physical hindrance. Polymers ${ }^{22}$ with long hydrophilic chains, such as Polyethylene Glycol (PEG) and Polyvinyl alcohol (PVA), are commonly used ${ }^{23-25}$ to avoid aggregation at physiological conditions ${ }^{26}$. Coating with polysaccharides such as dextran provides another approach to stabilizing these particles and is commonly used in commercial iron oxide nanoparticle MRI contrast agents ${ }^{27}$.

These surface modifications usually influence SPION size and biodistribution. Because they are bigger than gadolinium molecules $\left(\mathrm{Gd}^{3+}\right)$, iron oxide nanoparticles usually have either a rapid hepatic uptake (when they are larger than $50 \mathrm{~nm})^{4,27}$, or a delayed hepatic or 
ReticuloEndothelial System (RES) uptake when they are below 40-50 nm ${ }^{28}$ and could even reach sites of inflammation by lymphocyte transport ${ }^{29}$. In contrast, $\mathrm{Gd}^{3+}$ complexes have a much faster renal clearance ${ }^{30}$ than SPIONs ${ }^{31}$. Surface functionalization seems to influence the biological behavior of iron oxide nanoparticles. When they are in contact with nanoparticles, plasma proteins usually adhere to their surface, leading to a size increase ${ }^{32}$. This phenomenon, called opsonization, influences the half-life and biodistribution of nanoparticles in vivo; the faster the proteins are adsorbed onto the surface, the faster the nanoparticles will be taken up by the RES ${ }^{33}$. Finally, the initial surface charge could also influence nanoparticle uptake, as it is commonly observed that negatively-charged nanoparticles have faster interactions with cells or organs ${ }^{34,35}$. Faure et al. also demonstrated that the clearance and biodistribution of pegylated gadolinium oxide nanoparticles were governed by both the polymer length and terminal group ${ }^{35}$. Ge et al. recently reported that meso-2,3-dimercaptosuccinic acid (DMSA)- $\mathrm{Fe}_{2} \mathrm{O}_{3}$ particles showed dose-dependent cytotoxicity to human aortic endothelial cells ${ }^{36}$ and highlighted the need for careful evaluation of these particles before their medical application.

Surface modification is a key parameter affecting the biodistribution of nanoparticles. The present study investigated the influence of surface coating and charge on the initial in vitro and in vivo behaviors of SPIONs. SPIONs were synthesized with similar crystallite and hydrodynamic sizes as the commercially-available carboxydextran-coated iron oxide MRI contrast agent (Resovist $\left.{ }^{\circledR}\right)$. They were functionalized with silanated polymer, methoxy$\mathrm{PEG}_{2000}{ }^{37,38}\left(\mathrm{PEG}_{2 \mathrm{k}}-\mathrm{Si}\right)$, or with a combination of $\mathrm{PEG}_{2 \mathrm{k}}-\mathrm{Si}$ and carboxylic acid (DMSA) ${ }^{39}$. These two types of nanoparticles were coated with the same stabilizing agent (PEG polymers), but had different charges, respectively neutral and negative. This new dual combination permitted us to obtain sterically stabilized pegylated SPIONs with thiol groups, providing negative charges and anchoring groups for further modification ${ }^{40}$. Three different 
particles were compared; one with dextran and an initial negative charge, one with PEG and an initial neutral charge, and one with PEG and an initial negative charge. The cytotoxicity and interactions of these SPIONs were studied in mouse macrophages (RAW 264.7) and human hepatic cells (HepG2). To further investigate the RES behavior, Transmission Electron Microscopy (TEM) was performed on RAW 264.7 cells to observe SPION internalization. Finally, these nanoparticles were studied by MRI to estimate their potential as contrast agents, their biodistribution, and their clearance. Histology staining was also carried out to confirm the in vivo behaviors of these SPIONs.

\section{Materials and methods}

\subsection{Materials}

\subsubsection{Reagents}

Iron (II) chloride tetrahydrate $\left(\mathrm{FeCl}_{2} \cdot 4 \mathrm{H}_{2} \mathrm{O}\right)$, iron (III) chloride hexahydrate $\left(\mathrm{FeCl}_{3} \cdot 6 \mathrm{H}_{2} \mathrm{O}\right)$, sodium hydroxide $(\mathrm{NaOH})$, hydrochloric acid $(\mathrm{HCl} 37 \%)$, nitric acid $\left(\mathrm{HNO}_{3}\right.$ 69\%), meso-2,3-dimercaptosuccinic acid (DMSA), $\mathrm{PEG}_{2 \mathrm{k}}\left(\right.$ molecular weight $\left.=2000 \mathrm{~g} \cdot \mathrm{mol}^{-1}\right)$, 3-isocyanatopropyltriethoxysilane (ICPTS), dibutyltin dilaurate (DBTL), n-hexane, and tetrahydrofuran (THF) were purchased from Sigma Aldrich and used without any further purification. THF was distilled over sodium metal and benzophenone just before use. 3-(4,5Dimethylthiazol-2-yl)-2,5-diphenyltetrazolium bromide (MTT) reagent and Prussian blue (Accustain ${ }^{\circledR}$ iron stain) were purchased from Sigma.

\subsubsection{Control iron oxide suspension used as an MRI contrast agent}

Resovist ${ }^{\circledR}$ from Schering is a negatively-charged carboxydextran SPION suspension used in the clinical context at the University Hospital of Dijon. This commercially available $\mathrm{MRI} \mathrm{T}_{2}$ contrast agent was used as a reference for this study ${ }^{8}$. 


\subsubsection{SPION preparation}

Naked SPIONs were synthesized using a classical co-precipitation protocol ${ }^{41,42}$. Briefly, a stoichiometric mixture of $20 \mathrm{~mL}$ of $2 \mathrm{M}$ iron II chloride solution and $80 \mathrm{~mL}$ of $1 \mathrm{M}$ iron III chloride solution (molar ratio of $\mathrm{Fe}^{\mathrm{III}}: \mathrm{Fe}^{\mathrm{III}}=1: 2$ ) was added dropwise to $800 \mathrm{~mL}$ of $0.75 \mathrm{M}$ $\mathrm{NaOH}$ solution $\left(25^{\circ} \mathrm{C}\right)$. The naked SPION suspension formed was then washed and peptized several times with $1 \mathrm{M} \mathrm{HNO}_{3}$ solution and water. The suspension was then dialyzed at $\mathrm{pH} 3$ with a $\mathrm{HNO}_{3}$ solution for 2 days, and was subsequently stored at this $\mathrm{pH}$. The particle concentration was $23 \mathrm{mg} \cdot \mathrm{mL}^{-1}$. X-Ray Diffraction (XRD) patterns of the nanoparticles were characteristic of the magnetite spinel structure $\left(\mathrm{Fe}_{3} \mathrm{O}_{4}\right)$ (results not shown).

$\mathrm{PEG}_{2 \mathrm{k}}-\mathrm{Si}$ was obtained by reacting ICPTS with $\mathrm{PEG}_{2 \mathrm{k}}{ }^{43}$ in anyhdrous THF at $60^{\circ} \mathrm{C}$ under nitrogen flow for $48 \mathrm{~h}$, with DBTL as a catalyst. The $\mathrm{PEG}_{2 \mathrm{k}}-\mathrm{Si}$ was then precipitated in hexane. Pegylated SPIONs were obtained as follows: 0.13 mmol of $\mathrm{PEG}_{2 \mathrm{k}}-\mathrm{Si}$ was dissolved in $40 \mathrm{~mL}$ ethanol/water (50/50: v/v), $\mathrm{pH} 4$, at $25^{\circ} \mathrm{C}^{43-45}$. One hundred milligrams of SPIONs were added and the reaction proceeded for $48 \mathrm{~h}$ under $\mathrm{N}_{2}$ flow. The suspension was then dialyzed with water for one week. The resultant nanoparticles were called PEG $_{2 \mathrm{k}}$-SPIONs.

$\mathrm{PEG}_{2 \mathrm{k}}-\mathrm{SPIONs}$ were also grafted with DMSA ${ }^{40}$. Pegylated particles were obtained as described above, except for the addition of $0.0439 \mathrm{mmol}$ of DMSA $2 \mathrm{~h}$ prior to the end of the reaction. The modified SPIONs were then sedimented 3 times at $\mathrm{pH} 3$ in the presence of a magnetic field, peptized at $\mathrm{pH} 10$, and adjusted to $\mathrm{pH}$ 7. These nanoparticles were called DMSA + PEG $_{2 \mathrm{k}}-$ SPIONs.

Naked SPIONs, PEG $_{2 \mathrm{k}}-\mathrm{SPIONs}$ and DMSA + PEG $_{2 \mathrm{k}}-\mathrm{SPIONs}$ are schematically represented in Figure 1-a. 


\subsubsection{Cell culture}

Macrophage cell types from mice with leukemia (RAW 264.7) and HepG2 hepatocytes from a human liver carcinoma were cultured in $10 \mathrm{~cm}$ diameter petri dishes, in DMEM medium supplemented with $10 \%$ fetal bovine serum (FBS).

\subsubsection{Animal study}

3 month old Swiss Albino mice (30 g) were purchased from the animal care unit of the University Hospital of Dijon.

\subsection{Physicochemical characterization}

The zeta potential $(\xi)$ and the hydrodynamic size $\left(d_{H}\right)$ of the nanoparticles were measured with a Malvern Zetasizer, using DTS Nano 4.20 software. The nanoparticle suspensions were diluted to approximately $200 \mu \mathrm{g} \cdot \mathrm{mL}^{-1}$ in $10^{-2} \mathrm{M} \mathrm{NaCl}$ solution. The $\mathrm{NaCl}$ stock solution had previously been filtered through a $0.8 \mu \mathrm{m}$ filter. The $\xi$ potentials of functionalized and naked SPION suspensions were measured from $\mathrm{pH} 3$ to $\mathrm{pH} 12$; $\mathrm{pH}$ was adjusted with $0.1 \mathrm{M} \mathrm{HCl}$ and $0.1 \mathrm{M} \mathrm{NaOH}$, respectively.

TEM observations were performed with a JEOL JEM-2100 instrument operating at 200 $\mathrm{kV}$. The copper grids were dipped in a dilute suspension of samples and left to dry completely before analysis. The mean size of the crystallites, $\mathrm{d}_{\mathrm{TEM}}$, was obtained from at least one hundred particles.

Specific surface area measurement of naked SPIONs was performed using a 5 isotherm point BET (Brunauer-Emett-Teller) method with a BELSORP-mini apparatus with $\mathrm{N}_{2}$ gas adsorption.

Thermogravimetric analyses (TGA) were performed with a symmetrical thermobalance (SETARAM TAG24). The heating rate was $2^{\circ} \mathrm{C} \cdot \mathrm{min}^{-1}$ up to $800^{\circ} \mathrm{C}$ under $\mathrm{N}_{2} / \mathrm{O}_{2}(0.12 / 0.04$ L. $\left.\mathrm{min}^{-1}\right)$. Sample weights were around 5 to $10 \mathrm{mg}$. Any weight loss was assumed to be due to 
polymer degradation. The amount of DMSA on the particles was measured with Ellman's reagent assay titration ${ }^{40,46}$.

The particle relaxivities $\left(\mathrm{r}_{2}\right.$ in $\left.\mathrm{mM}_{\mathrm{Fe}}{ }^{-1} \cdot \mathrm{s}^{-1}\right)$ were calculated using the following method ${ }^{47}$. Water proton transverse relaxation time $\left(\mathrm{T}_{2}\right)$ measurements at $3.0 \mathrm{~T}$ were carried out at $298 \pm$ $1 \mathrm{~K}$ with a Siemens Magnetom Trio TIM, using a commercially-available birdcage head coil. Relaxation time measurements were performed on test tubes containing SPIONs, with or without surface modification, in acrylamide gel at a range of concentrations $(0,0.013,0.038$, $0.063,0.088,0.125$, and $0.25 \mathrm{mM}_{\mathrm{Fe}}$ ). For $\mathrm{T}_{2}$ determination, a multi-echo spin-echo (SE) pulse sequence was used, with $\mathrm{T}_{\mathrm{R}}$ (repletion time) $=5000 \mathrm{~ms}$, matrix $=256 \times 204$, Field of View $(\mathrm{FOV})=100 \times 80 \mathrm{~mm}$ and slice thickness $=5 \mathrm{~mm}$. Images were acquired at 32 echoes, from $\mathrm{T}_{\mathrm{E}}=8.2 \mathrm{~ms}$ to $275.2 \mathrm{~ms}$, with an $8.2 \mathrm{~ms}$ interval. Image analysis was performed using ImageJ (Image Analysis Software developed by the NIH, USA). The signal decay curve was fitted to the equation $\mathrm{S}\left(\mathrm{T}_{\mathrm{E}}\right)=\mathrm{A} \exp \left(-\mathrm{T}_{\mathrm{E}} / \mathrm{T}_{2}\right)$ using a non-linear function. The relaxivity, $\mathrm{r}_{2}$ (in $\mathrm{mM}^{-}$ $\left.{ }_{\mathrm{Fe}}^{1} \cdot \mathrm{s}^{-1}\right)$, was then determined by fitting the relaxation rate $\left(1 / \mathrm{T}_{2}\right)$ as a function of iron concentration in $\mathrm{mM}_{\mathrm{Fe}}$.

\subsection{Biological observations}

\subsubsection{Cell viability}

The MTT assay was used to measure the cytotoxicity of SPIONs in two different cell lines (RAW 264.7 and HepG2). This measured mitochondrial metabolic activity, which converted the MTT reagent from a yellow tetrazolium salt to the dark blue formazan by reductive cleavage of the tetrazolium ring. Formazan crystals were then dissolved in an organic solvent and quantified by measurement of the absorbance of the solution at $570 \mathrm{~nm}$, with the resultant value being proportional to the number of living cells. To determine cell viability, the cells were seeded in a 96-well plate and incubated at $37^{\circ} \mathrm{C}$ in a $5 \% \mathrm{CO}_{2}$ atmosphere for $24 \mathrm{~h}$ until they reached $50 \%$ confluency. Cells were then incubated in the 
presence of the different types of SPIONs or Resovist ${ }^{\circledR}$ (at two concentrations: 25 and 50 $\mu \mathrm{g}_{\mathrm{Fe} .} \mathrm{cm}^{-2}$ well area), and physiological saline $(\mathrm{NaCl}$ at $0.15 \mathrm{M})$. These two concentrations were chosen on the basis of the dose injected in the in vivo study. Briefly, $5.6 \mu \mathrm{g}_{\mathrm{Fe}} \mathrm{g}^{-1}$ mouse were injected ( $30 \mathrm{~g}$ mice, $2 \mathrm{~mL}$ of circulating blood ${ }^{48}$ ), i.e. $168 \mu \mathrm{g}_{\mathrm{Fe}} /$ mouse and $84 \mu \mathrm{g} . \mathrm{ml}^{-1}$ blood. In 96-well plates, the working volume was $100 \mu \mathrm{L}$ so we selected $8.4 \mu \mathrm{g}_{\mathrm{Fe}} /$ well (about $25 \mu \mathrm{g}_{\mathrm{Fe}} . \mathrm{cm}^{-2}$ since each well had a surface area of $0.32 \mathrm{~cm}^{2}$ ). This concentration was then doubled for high-dose cytotoxicity assessment. Previous studies have employed these doses to investigate both MRI biodistribution and cytotoxicity (MTT assays) of SPIONs ${ }^{49,50}$. After 1 , 3 , and $24 \mathrm{~h}$ of incubation, the wells were washed 2 times with PBS at $37^{\circ} \mathrm{C}$. Then $100 \mu \mathrm{L}$ MTT (2 mg. $\left.\mathrm{mL}^{-1}\right)$ was added in Puck G+ medium (126.6 mM NaCl, $3.8 \mathrm{mM} \mathrm{KCl}, 0.11 \mathrm{mM}$ $\mathrm{CaCl}_{2} \cdot 2 \mathrm{H}_{2} \mathrm{O}, 0.62 \mathrm{mM} \mathrm{MgSO} \cdot 7 \mathrm{H}_{2} \mathrm{O}, 0.86 \mathrm{mM} \mathrm{Na} \mathrm{HPO}_{4} \cdot 2 \mathrm{H}_{2} \mathrm{O}, 0.61 \mathrm{mM} \mathrm{KH} \mathrm{KO}_{4}, 14.3$ $\mathrm{mM} \mathrm{NaHCO} 3$, and 1.1 g.L $\mathrm{L}^{-1}$ glucose, $\mathrm{pH}$ 7.4) for $1 \mathrm{~h}$ at $37^{\circ} \mathrm{C}$. Puck G+ corresponded to basic osmotic medium and was used to avoid interference during the MTT reaction. Excess MTT was then removed and $200 \mu \mathrm{L}$ of isopropanol with $\mathrm{HCl}(0.1 \mathrm{M})$ was incubated with the cells for $1 \mathrm{~h}$ at room temperature. The absorbance in each well was then read in a spectrophotometer (Wallac Victor3, Perkin Elmer) at $570 \mathrm{~nm}$. Average absorbance (from $\mathrm{n}=$ 4) was normalized to the control. The viability (in \%) was then calculated by absorbance $_{\text {test }} /$ absorbance $_{\text {control }} \times 100$.

\subsubsection{SPION interactions with macrophages and hepatocytes}

Optical microscopy: RAW 264.7 and HepG2 cells seeded on $1 \mathrm{~cm}$ diameter glass coverslips in 24-well plates were incubated for $3 \mathrm{~h}$ in the presence of Resovist ${ }^{\circledR}, \mathrm{PEG}_{2 \mathrm{k}}-$ SPIONs, or DMSA + PEG $_{2 \mathrm{k}}$-SPIONs at a concentration of $25 \mu \mathrm{g}_{\mathrm{Fe}} \cdot \mathrm{cm}^{-2}$. The cells were then washed 2 times with PBS and fixed with $4 \%$ paraformaldehyde, $0.5 \%$ glutaraldehyde, and $0.1 \%$ triton for $15 \mathrm{~min}$. Then the cells were fixed in sodium borohydride ( $25 \mathrm{mg} \cdot \mathrm{mL}^{-1}$ in PBS) for $10 \mathrm{~min}$, washed once with PBS, incubated with $2 \%$ potassium ferrocyanide and 0.6 
$\mathrm{mmol} / \mathrm{L} \mathrm{HCl}$ for $10 \mathrm{~min}$, and washed with water. Cells were then stained with $0.2 \%$ paroraxilin for $1 \mathrm{~min}$, before washing consecutively with water, 95\% and 100\% ethanol, and $100 \%$ xylene for $10 \mathrm{~min}$. The dissolved iron from the SPIONs reacted with potassium ferrocyanide to give a blue product. The cells were then mounted on glass slides using Eukitt® (Sigma) and observed by optical microscopy. RAW 264.7 and HepG2 cells incubated with complete media were observed as control.

Transmission Electron Microscopy: RAW 264.7 cells were incubated with Resovist ${ }^{\text {, }}$ $\mathrm{PEG}_{2 \mathrm{k}}$-SPIONs, or DMSA + $\mathrm{PEG}_{2 \mathrm{k}}-\mathrm{SPIONs}$ at a concentration of $25 \mu \mathrm{g}_{\mathrm{Fe} .} \mathrm{cm}^{-2}$. Cells were then washed 3 times with PBS and fixed at room temperature with 4\% paraformaldehyde and $1.5 \%$ glutaraldehyde in a phosphate buffer $(0.1 \mathrm{M}, \mathrm{pH} 7.4)$ for $30 \mathrm{~min}$. The cells were then washed 4 times in phosphate buffer and then one last time overnight at $4^{\circ} \mathrm{C}$. Cells were then post-fixed using $1 \%$ osmium tetraoxide solution in phosphate buffer, washed and dehydrated by 15 min incubations in successive ethanol baths (from $30 \%$ to $100 \%$ ). Cells were then embedded in epoxy resin (EMBed-812) overnight at $37^{\circ} \mathrm{C}$, followed by $48 \mathrm{~h}$ at $60^{\circ} \mathrm{C}$. Resins were then cut with an ultramicrotome (slices from 80 to $90 \mathrm{~nm}$ ). After cutting, the slices were stained with uranyl acetate and lead citrate solution for contrast enhancement and observed by TEM on a HITACHI H-7500 operating at $80 \mathrm{kV}$.

\subsubsection{Mice MRI analyses}

Mice were injected with $100 \mu \mathrm{L}$ of physiological saline $(\mathrm{NaCl}$ at $0.15 \mathrm{M})(\mathrm{n}=6)$, Resovist ${ }^{\circledR}(n=6)$, PEG $_{2 k-S P I O N s}(n=6)$, or DMSA + PEG $2 k-S P I O N s ~(n=4)$. SPION suspensions were diluted in physiological saline to a concentration of $1.68 \mathrm{mg}_{\mathrm{Fe}} \cdot \mathrm{mL}^{-1}$. To reach a concentration of $5.6 \mathrm{mg}_{\mathrm{Fe}} \cdot \mathrm{kg}^{-1}$ mouse, the injected dose was around $168 \mu \mathrm{g}_{\mathrm{Fe}}$ per mouse. This experiment was conducted in accordance with French ethical guidelines for in vivo studies (authorization number B0410). 
Injected mice were then analyzed by $3.0 \mathrm{~T}$ MRI at 1,3 , and $24 \mathrm{~h}$ after injection. Gradient echo $\mathrm{T}_{2}{ }^{*}$ weighted was used for acquisition with echo-time $\mathrm{TE}=2.9 \mathrm{~ms}$, repetition time $\mathrm{T}_{\mathrm{R}} \mathrm{W}$ $=300 \mathrm{~ms}$, slice thickness $=2 \mathrm{~mm}$ and an in-plane resolution of $0.35 \mu \mathrm{m}^{2}$. Images were acquired in sagittal, longitudinal and transverse slice orientations. On coronal images, the average contrast of the liver was calculated using Image $\mathbf{J}$ and reported in grey level (where 0 was full black and 2048 was full white). Half of each mouse population was sacrificed $3 \mathrm{~h}$ after injection for organ analysis and the other half was sacrificed after $24 \mathrm{~h}$.

\subsubsection{SPION distribution in organs}

The livers and hearts of the sacrificed mice were harvested and sliced. These organs were then treated with Prussian blue to reveal the presence of iron from dissolved SPIONs. Optical microscopy was then performed on the slices and the images obtained from test and control animals were compared.

\subsubsection{Statistics}

All statistics were performed using the GraphPad Prism software and an unpaired t-test.

\section{Results and discussion}

\subsection{Physicochemical characterization of SPIONs}

Some physicochemical characteristics of the synthesized and functionalized SPIONs are summarized in Table 1 and compared to those of the commercial Resovist ${ }^{\circledR}$ SPION suspension used as the reference nanomaterial in this study. No significant differences were observed in the crystallite sizes of Resovist ${ }^{\circledR}$ and the synthesized SPIONs. The hydrodynamic diameter of naked SPIONs increased to around $40 \mathrm{~nm}$ after $\mathrm{PEG}_{2 \mathrm{k}}$ functionalization. This size was close to that of Resovist ${ }^{\circledR}$. The major difference between $\mathrm{PEG}_{2 \mathrm{k}}-\mathrm{SPIONs}$ and Resovist ${ }^{\circledR}$ was their charge. At $\mathrm{pH} 7$, Resovist ${ }^{\circledR}$ was negatively charged, while PEG $_{2 \mathrm{k}-S P I O N s}$ were only slightly negatively charged (almost neutral). The addition of 0.3 molecule of DMSA per $\mathrm{nm}^{2}$ of $\mathrm{PEG}_{2 \mathrm{k}-\mathrm{SPIONs}}$ did not change the size of the nanoparticles, but induced a negative 
charge $(\xi=-30 \mathrm{mV})$ at $\mathrm{pH} 7$. According to the study performed by Fauconnier et al. ${ }^{51}$, the maximum concentration of DMSA/nm² should be around 2. However, Ge et al. demonstrated that this concentration could induce some cytotoxicity ${ }^{36}$. The lower DMSA concentration and the presence of PEG grafted on the surface of DMSA + PEG $_{2 k}-$ SPIONs should decrease the potential for cytotoxicity. The presence of DMSA on these SPIONs also decreased the PEG density on the surface from 3.3 to 0.6 molecule $/ \mathrm{nm}^{2}$, probably by removing excess of polymer from the surface of the SPION. The relaxivities $\left(\mathrm{r}_{2}\right)$ were all in the same range, regardless of the nature of the surface coating. These measurements confirmed that all of the SPIONs had roughly the same size because the relaxation time $\left(T_{2}\right)$ linked to $r_{2}$ was size-dependent ${ }^{15,52,53}$. It has also been demonstrated that greater aggregation of magnetic particles could increase $r_{2}$ ${ }^{54}$ by increasing the presence of magnetic mono-domains in the aggregates ${ }^{55}$. In addition, LaConte et al. recently showed that the charges of these nanoparticles did not influence $\mathrm{r}_{2}{ }^{56}$. Finally, the concentration (molecule/nm²) at which the SPIONs were coated with either carboxydextran or $\mathrm{PEG}_{2 \mathrm{k}}$, with or without DMSA, did not influence their magnetic properties. These similarly-sized nanoparticles were studied in vitro and in vivo to determine the potential influence of their initial surface charge and coating on their biological behaviors. Figure 1-b shows the $\zeta$ potentials of naked SPIONs, PEG $_{2 \mathrm{k}}-\mathrm{SPIONs}$, and DMSA $+\mathrm{PEG}_{2 \mathrm{k}}-\mathrm{SPIONs}$ at different $\mathrm{pH}$ conditions (from 3 to 12). The isoelectric point of naked and $\mathrm{PEG}_{2 \mathrm{k}}$ SPIONs was around $\mathrm{pH} 7$, showing the absence of charge on these two types of nanoparticles. However, the absolute $\zeta$ values of $\mathrm{PEG}_{2 \mathrm{k}}$-SPIONs $(+10 \mathrm{mV})$ were lower than those of naked SPIONs $(+40 \mathrm{mV})$ at acidic $\mathrm{pH}$; this shielding effect proved that $\mathrm{PEG}_{2 \mathrm{k}}$ had been efficiently grafted onto the SPIONs. For the DMSA + PEG $_{2 \mathrm{k}}-\mathrm{SPIONs}$, the isoelectric point was below $\mathrm{pH} 3$, proving that these particles were negatively charged at the $\mathrm{pH}$ range used in subsequent analyses. 
The cytotoxicity of naked and functionalized-SPIONs was evaluated in macrophages (RAW 264.7) and hepatic cells (HepG2), as shown in


Figure 2. These two cell lines were chosen to model the usual in vivo targets of SPIONs: the RES and the liver. Compared with control cells, 24-h incubations with the two test concentrations (25 and $50 \mu \mathrm{g}_{\mathrm{Fe}} \mathrm{cm}^{-2}$ ) of functionalized nanoparticles did not produce significant cytotoxicity, with cell viability remaining above $80 \%$ (Figure 2 ). The unexpectedly high assay values observed (only at the high concentration, after a 24-h incubation with one cell line) may have been due to interference between iron oxide and the assay.

Prussian blue staining experiments were carried out on RAW 264.7 and HepG2 cells incubated for $3 \mathrm{~h}$ in the presence of the three different functionalized SPIONs (at $25 \mu \mathrm{g}_{\mathrm{Fe} . \mathrm{cm}^{-2}}$ of well) and compared with control cells, incubated with medium only (Figure 3). Blue colored spots observed on the images were caused by Prussian blue reacting with iron (dissolved from SPIONs) and potassium ferrocyanide. Thus, SPION-containing areas were labeled with the blue pigment. In RAW 264.7 cells incubated with Resovist ${ }^{\circledR}$, blue spots co- 
localized with the cells. No blue spots were observed at this magnification in RAW 264.7 cells incubated with PEG $_{2 \mathrm{k}-\mathrm{SPIONs}}$, while many were observed in and around these cells following incubation with DMSA + PEG $_{2 \mathrm{k}}$ SPIONs. The distribution of the blue stain in the latter case may have indicated some stronger interactions between these nanoparticles and RAW 264.7 cells. This could reflect particle aggregation under these experimental conditions. Resovist ${ }^{\circledR}$ was also found to co-localize with HepG2 cells. Although very few PEG $_{2 k-S P I O N s}$ seemed to have interacted with HepG2 cells, DMSA + PEG $_{2 \mathrm{k}-}$ SPIONs interacted more with these cells. Some aggregations of these latter particles were observed on these hepatic cells, but not to the extent found on RAW 264.7 macrophage cells. These observations suggested that these particles had aggregated in some places before their dissolution and reaction with potassium ferrocyanide. As the Prussian blue was observed with an optical microscope, it was not possible to distinguish between co-localization and real internalization of the particles. However, these results showed that DMSA + PEG $_{2 k}$ SPIONs interacted more with the cells than PEG $_{2 \mathrm{k}}$-SPIONs, which may be due to their surface charge and some aggregation of the negatively-charged particles. Moreover, Resovist ${ }^{\circledR}$ particles did not show any obvious aggregation (compared to DMSA $+\mathrm{PEG}_{2 \mathrm{k}}$ ) but showed more interaction with cells than


because of their phagocytosis role in vivo. Regarding cellular uptake, there was no evidence



To obtain more insight into these interactions, TEM observations of RAW 264.7 cells incubated for $3 \mathrm{~h}$ with the three different nanoparticles (at $25 \mu \mathrm{g}_{\mathrm{Fe}} . \mathrm{cm}^{-2}$ of well) were carried out (Figure 4). Resovist ${ }^{\circledR}$ (top images) and DMSA + PEG $2 \mathrm{k}-\mathrm{SPIONs}$ (bottom images) were easy to detect inside vesicles that were probably phagosomes. As observed in the optical Prussian blue staining, the SPIONs were aggregated, with sizes greater than 100 to $200 \mathrm{~nm}$ for Resovist ${ }^{\circledR}$ and around $500 \mathrm{~nm}$ for DMSA + PEG $_{2 \mathrm{k}-S P I O N s}$. These particles were entrapped 
and therefore concentrated in vesicles. It was obvious from these observations that their sizes had increased from 40-50 nm (Table 1, PCS measurements) to a few hundred $\mathrm{nm}$ in contact with cells and their medium. This phenomenon has been described previously under biological conditions. For instance, Schlorf et al. reported the aggregation effect of fibrinogen and plasma after a 1-h incubation with dextran-coated SPIONs ${ }^{57}$. In addition, Khandhar et al. showed that the Resovist ${ }^{\circledR}$ response to MPS (Magnetic Particle Spectrometry) characterization was modified after incubation with media ${ }^{58}$ while their neutral Poly(maleic anhydride-alt-1-octadecene) (PMAO)-PEG-coated iron oxide nanoparticles remained

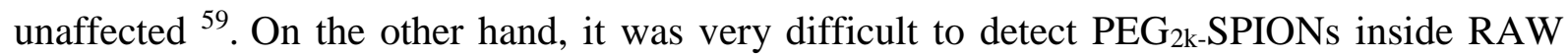
264.7 cells, even at a high magnification. The small black dots around $50 \mathrm{~nm}$ circled in yellow in Figure 4 could potentially be pegylated SPIONs, because the electron contrast was slightly higher than the background. Consequently, some PEG $_{2 k}$ SPIONs could be present inside vesicles, but in very small quantities (compared with other conditions) and with small sizes, as they were not detected with Prussian blue staining. No aggregates of PEG $_{2 k}$-SPIONs were detected inside RAW 264.7 cells following a meticulous observation by TEM. These results suggested that $\mathrm{PEG}_{2 \mathrm{k}-\mathrm{SPIONs}}$ were more stable under biological conditions than the other nanoparticles tested.

Optical and electron microscopy observations demonstrated that the negatively charged particles interacted more with hepatic (HepG2) and macrophage (RAW 264.7) cell lines than did pegylated neutral nanoparticles. Resovist ${ }^{\circledR}$ and DMSA + PEG $_{2 \mathrm{k}-S P I O N s}$ were internalized in vesicles of around $500 \mathrm{~nm}$ and were easily detectable by Prussian blue staining or in TEM. In contrast, PEG $_{2 \mathrm{k}-}$ SPIONs were more difficult to observe in the cell cultures and this could be due to a reduced internalization of these nanoparticles by RAW 264.7 and HepG2 cells. If these PEG $_{2 \mathrm{k}}$-SPIONs avoid being taken up by RES cells, they could remain in the blood circulation for longer than the negatively-charged particles tested. 
Swiss albino mice were injected with physiological saline or $168 \mu \mathrm{g}_{\mathrm{Fe}}$ of Resovist ${ }^{\circledR}$, $\mathrm{PEG}_{2 \mathrm{k}}$-SPIONs, or DMSA + PEG $_{2 \mathrm{k}}-\mathrm{SPIONs}$. Mice were then analyzed using MRI at 1,3 , and $24 \mathrm{~h}$ after injection. On the coronal images obtained $3 \mathrm{~h}$ after injection (Figure 5a, livers circled in red), liver and heart contrasts were analyzed and reported in arbitrary units (Figure $5 b$ and 5c). On the MRI images of Figure 5a, the liver of the control mouse appeared less dark than the livers of SPION-injected mice. Moreover, the liver of mice injected with $\mathrm{PEG}_{2 \mathrm{k}^{-}}$ SPIONs looked less dark than the other two. This result was confirmed by quantification, showing a significant difference (Figure 5b). No other difference in contrast was observed in any other organ during the whole experiment. As shown in Figure 5b, the average contrast of control mice livers did not change significantly during the experiment (around 700 to 800 a.u.), which suggested that there was no physiological influence on contrast during the experiment. For mice injected with SPIONs, the average contrast of the livers decreased significantly after $1 \mathrm{~h}$, illustrating the negative contrast effect of the SPIONs on this organ. For the negatively-charged particles, the liver contrast reached final values of 50-100 a.u. $1 \mathrm{~h}$


similar values of around 100 a.u. $24 \mathrm{~h}$ after injection, the contrast was relatively high, around 500 and 400 a.u. at 1 and $3 \mathrm{~h}$ post-injection, respectively. As the final contrast value of $\mathrm{PEG}_{2 \mathrm{k}-}$ SPIONs after $24 \mathrm{~h}$ was similar to that of the other SPIONs, and all the nanoparticles had approximately the same $\mathrm{r}_{2}$ relaxivities, this indicated that the $\mathrm{PEG}_{2 \mathrm{k}}$ SPIONs accumulated less in the liver 1 and $3 \mathrm{~h}$ after injection and would therefore probably have remained in the circulation during this period. For other organ, no significant differences were observed between the contrast of control and injected mice, as shown for the heart in Figure 5c. The functionalized SPIONs used during this study therefore only showed a negative contrast in the liver. Moreover, neutral pegylated SPIONs seemed to be taken-up more slowly than their negatively-charged counterparts. 
Prussian blue staining of livers and hearts was conducted to determine whether less $\mathrm{PEG}_{2 \mathrm{k}-\mathrm{SPIONs}}$ were taken up by the liver than Resovist ${ }^{\circledR}$ and DMSA + PEG $2 \mathrm{k}-\mathrm{SPIONs}$ (Figure 6). As the slices observed were taken in the middle of the organs, any nanoparticles detected were assumed to have been taken up by the organ. Firstly, no SPIONs were observed in heart slices, consistent with the MRI findings. However, livers from mice injected with SPIONs had blue spots, revealing the presence of iron oxide nanoparticles, even $3 \mathrm{~h}$ after injection. It is also important to note that fewer blue spots were observed in $\mathrm{PEG}_{2 \mathrm{k}-\mathrm{SPION} \text { - }}$ injected mice than in mice administered with the other two types of nanoparticle. By $24 \mathrm{~h}$ after injection, the quantity of SPIONs appeared to be very similar. These Prussian blue observations, coupled with the MRI images and contrast analyses, demonstrated that less $\mathrm{PEG}_{2 \mathrm{k}-S P I O N s}$ were taken up by the liver $3 \mathrm{~h}$ after injection, whereas approximately all the Resovist ${ }^{\circledR}$ and DMSA + PEG $_{2 \mathrm{k}-S P I O N s}$ were within the liver, even $1 \mathrm{~h}$ after injection.

One of the reasons for these observations of lower liver uptake of $\mathrm{PEG}_{2 \mathrm{k}-\mathrm{SPIONs}}$, compared with the negatively-charged SPIONs, could be explained by the in vitro results. Internalization experiments showed less internalization of PEG $_{2 k}$ SPIONs by hepatic and

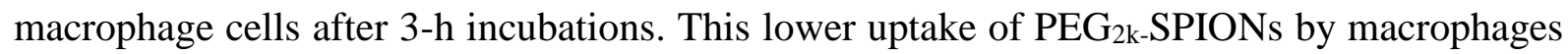
could help explain their longer circulation time. With PEG, the opsonization of particles by blood proteins and their subsequent uptake by macrophages is usually slower ${ }^{32}$, resulting in an extended blood circulation of PEG-coated nanoparticles which could limit the negative contrast of the liver. These protein adsorption differences have also been observed in vitro. The agglomerated SPIONs seen on Prussian blue microscopy imaging could be due to interactions between SPIONs and plasma proteins (usually albumin) ${ }^{60}$. The absence of


compared with those that were negatively-charged. However this phenomenon could not fully explain the longer blood circulation observed with $\mathrm{PEG}_{2 \mathrm{k}}-\mathrm{SPIONs}$, because DMSA $+\mathrm{PEG}_{2 \mathrm{k}^{-}}$ 
SPIONs also had PEG on their surface. The negative charge of these latter SPIONs could provide an explanation for their increased interactions with hepatic cells ${ }^{35,61}$. It was observed that DMSA + PEG $_{2 k}$-SPIONs tended to be taken up more by hepatocytes than PEG $_{2 k-}$ SPIONs, leading to a longer latency in liver than the negatively-charged particles. Moreover, when the SPIONs were charged at physiological $\mathrm{pH}$, they aggregated in the presence of cells and their medium. A final surface charge-related explanation for the slow liver uptake of only $\mathrm{PEG}_{2 \mathrm{k}}$-SPIONs is the aggregation of negatively-charged SPIONs. It has already been reported that particles larger than $40 \mathrm{~nm}$ are easily taken up by the liver ${ }^{7,62-64}$. In the present study, the microscopy observations were consistent with this theory.

\section{Conclusion}

This study prepared and investigated two different types of SPIONs as potential MRI contrast agents and compared them to commercial SPIONs (Resovist $\left.{ }^{\circledR}\right)$ that were coated with carboxydextran and negatively-charged.

In conclusion, it was observed that negatively-charged and pegylated nanoparticles had the same biological behavior (cytotoxicity, cellular internalization, and MRI biodistribution) as nanoparticles coated with negatively-charged carboxydextran, even though the surfaces of these particles were very different. The results indicated that the biological behavior of nanoparticles with similar sizes and magnetic properties was mainly governed by the charge, rather than the coating. However, the nature of the coating may also play a role as the density of $\mathrm{PEG}_{2 \mathrm{k}}$ was much lower with DMSA than without it.

\section{Acknowledgements}

We gratefully thank Dr. R. Chassagnon (ICB Laboratory) for the TEM experiments on nanoparticles, B. Gasquet (Plateau Technique Imagerie Cellulaire IFR Santé STIC) for the preparation of biological samples and imaging, Dr. L. Crowe from the University Hospital of 
Geneva for providing the Resovist ${ }^{\circledR}$, and both the CNRS (Centre National de la Recherche Scientifique) and Conseil Regional de Bourgogne for financial support. 


\section{References}

1. Q. A. Pankhurst, N. T. K. Thanh, S. K. Jones, J. Dobson, Progress in Applications of Magnetic Nanoparticles in Biomedicine, J. Phys. -Appl. Phys. 42 (2009).

2. I. Hilger, W. A. Kaiser, Iron Oxide-Based Nanostructures for MRI and Magnetic Hyperthermia, Nanomed. 7, 1443-1459 (2012).

3. A. K. Gupta, R. R. Naregalkar, V. D. Vaidya, M. Gupta, Recent Advances on Surface Engineering of Magnetic Iron Oxide Nanoparticles and Their Biomedical Applications, Nanomed. 2, 23-39 (2007).

4. Z. L. Zhang, R. Dharmakumar, N. Mascheri, Z. Y. Fan, S. Y. Wu, D. B. Li, Comparison of Superparamagnetic and Ultrasmall Superparamagnetic Iron Oxide Cell Labeling for Tracking Green Fluorescent Protein Gene Marker with Negative and Positive Contrast Magnetic Resonance Imaging, Mol. Imaging 8, 148-155 (2009).

5. F. Liu, S. Laurent, H. Fattahi, L. V. Elst, R. N. Muller, Superparamagnetic Nanosystems Based on Iron Oxide Nanoparticles for Biomedical Imaging, Nanomed. 6, 519-528 (2011).

6. R. Singh, H. S. Nalwa, Medical Applications of Nanoparticles in Biological Imaging, Cell Labeling, Antimicrobial Agents, and Anticancer Nanodrugs, J. Biomed. Nanotechnol. 7, 489-503 (2011).

7. Y. X. J. Wang, S. M. Hussain, G. P. Krestin, Superparamagnetic Iron Oxide Contrast Agents: Physicochemical Characteristics and Applications in MR Imaging, Eur. Radiol. 11, 2319-2331 (2001).

8. P. Reimer, T. Balzer, Ferucarbotran (Resovist): A New Clinically Approved RESSpecific Contrast Agent for Contrast-Enhanced MRI of the Liver: Properties, Clinical Development, and Applications, Eur. Radiol. 13, 1266-1276 (2003).

9. K.-J. Chen, S. M. Wolahan, H. Wang, C.-H. Hsu, H.-W. Chang, A. Durazo, L.-P. Hwang, M. A. Garcia, Z. K. Jiang, L. Wu, Y.-Y. Lin, H.-R. Tseng, A Small MRI Contrast Agent Library of gadolinium(III)-Encapsulated Supramolecular Nanoparticles for Improved Relaxivity and Sensitivity, Biomaterials 32, 2160-2165 (2011).

10. P. Poix, Sur Une Methode de Determination Des Distances Cation-Oxygene Dans Les Oxydes Mixtes a Structure Spinelle - Application Des Valeurs a Quelques Cas Particuliers, Bull. Soc. Chim. Fr., 1085-1087 (1965).

11. T. Belin, N. Millot, N. Bovet, M. Gailhanou, In Situ and Time Resolved Study of the Gamma/alpha-Fe2O3 Transition in Nanometric Particles, J. Solid State Chem. 180, 2377-2385 (2007).

12. J. L. Dormann, D. Fiorani, E. Tronc, Magnetic Relaxation in Fine-Particle Systems, Adv. Chem. Phys. 98, 283-494 (1997).

13. S. Laurent, D. Forge, M. Port, A. Roch, C. Robic, L. V. Elst, R. N. Muller, Magnetic Iron Oxide Nanoparticles: Synthesis, Stabilization, Vectorization, Physicochemical Characterizations, and Biological Applications, Chem. Rev. 108, 2064-2110 (2008).

14. H. Duan, M. Kuang, X. Wang, Y. A. Wang, H. Mao, S. Nie, Reexamining the Effects of Particle Size and Surface Chemistry on the Magnetic Properties of Iron Oxide Nanocrystals: New Insights into Spin Disorder and Proton Relaxivity, J. Phys. Chem. C 112, 8127-8131 (2008).

15. U. I. Tromsdorf, N. C. Bigall, M. G. Kaul, O. T. Bruns, M. S. Nikolic, B. Mollwitz, R. A. Sperling, R. Reimer, H. Hohenberg, W. J. Parak, S. Forster, U. Beisiegel, G. Adam, H. Weller, Size and Surface Effects on the MRI Relaxivity of Manganese Ferrite Nanoparticle Contrast Agents, Nano Lett. 7, 2422-2427 (2007).

16. S. Campelj, D. Makovec, M. Drofenik, Functionalization of Magnetic Nanoparticles with 3-Aminopropyl Silane, J. Magn. Magn. Mater. 321, 1346-1350 (2009). 
17. C. M. Cheng, G. Kou, X. L. Wang, S. H. Wang, H. C. Gu, Y. J. Guo, Synthesis of Carboxyl Superparamagnetic Ultrasmall Iron Oxide (USPIO) Nanoparticles by a Novel Flocculation-Redispersion Process, J. Magn. Magn. Mater. 321, 2663-2669 (2009).

18. T. J. Daou, S. Begin-Colin, J. M. Greneche, F. Thomas, A. Derory, P. Bernhardt, P. Legare, G. Pourroy, Phosphate Adsorption Properties of Magnetite-Based Nanoparticles, Chem. Mater. 19, 4494-4505 (2007).

19. L. Maurizi, F. Bouyer, J. Paris, F. Demoisson, L. Saviot, N. Millot, One Step Continuous Hydrothermal Synthesis of Very Fine Stabilized Superparamagnetic Nanoparticles of Magnetite, Chem. Commun. 47, 11706-11708 (2011).

20. X. F. Xue, K. Hanna, C. Despas, F. Wu, N. S. Deng, Effect of Chelating Agent on the Oxidation Rate of PCP in the magnetite/H2O2 System at Neutral pH, J. Mol. Catal. Chem. 311, 29-35 (2009).

21. L. Maurizi, U. Sakulkhu, L. A. Crowe, V. M. Dao, N. Leclaire, J.-P. Vallée, H. Hofmann, Syntheses of Cross-Linked Polymeric Superparamagnetic Beads with Tunable Properties, RSC Adv. 4, 11142-11146 (2014).

22. M. Chanana, Z. Mao, D. Wang, Using Polymers to Make Up Magnetic Nanoparticles for Biomedicine, J. Biomed. Nanotechnol. 5, 652-668 (2009).

23. M. D. Butterworth, L. Illum, S. S. Davis, Preparation of Ultrafine Silica- and PEGCoated Magnetite Particles, Colloids Surf. -Physicochem. Eng. Asp. 179, 93-102 (2001).

24. A. Petri-Fink, M. Chastellain, L. Juillerat-Jeanneret, A. Ferrari, H. Hofmann, Development of Functionalized Superparamagnetic Iron Oxide Nanoparticles for Interaction with Human Cancer Cells, Biomaterials 26, 2685-2694 (2005).

25. S. Nayar, A. Guha, A Novel Biomimetic Material-Glycine-PVA Ferrofluid That Crosses the Blood-Brain Barrier, J. Biomed. Nanotechnol. 7, 78-78 (2011).

26. L. Kaufner, R. Cartier, R. Wuestneck, I. Fichtner, S. Pietschmann, H. Bruhn, D. Schuett, A. F. Thuenemann, U. Pison, Poly(ethylene Oxide)-Block-Poly(glutamic Acid) Coated Maghemite Nanoparticles: In Vitro Characterization and in Vivo Behaviour, Nanotechnology 18 (2007).

27. P. Reimer, B. Tombach, Hepatic MRI with SPIO: Detection and Characterization of Focal Liver Lesions, Eur. Radiol. 8, 1198-1204 (1998).

28. V. Dousset, L. Ballarino, C. Delalande, M. Coussemacq, P. Canioni, K. G. Petry, J. M. Caille, Comparison of Ultrasmall Particles of Iron Oxide (USPIO)-Enhanced T2Weighted, Conventional T2-Weighted, and Gadolinium-Enhanced T1-Weighted MR Images in Rats with Experimental Autoimmune Encephalomyelitis, Am. J. Neuroradiol. 20, 223-227 (1999).

29. A. Bjornerud, L. Johansson, The Utility of Superparamagnetic Contrast Agents in MRI: Theoretical Consideration and Applications in the Cardiovascular System, Nmr Biomed. 17, 465-477 (2004).

30. A. J. L. Villaraza, A. Bumb, M. W. Brechbiel, Macromolecules, Dendrimers, and Nanomaterials in Magnetic Resonance Imaging: The Interplay between Size, Function, and Pharmacokinetics, Chem. Rev. 110, 2921-2959 (2010).

31. C. Sun, J. S. H. Lee, M. Q. Zhang, Magnetic Nanoparticles in MR Imaging and Drug Delivery, Adv. Drug Deliv. Rev. 60, 1252-1265 (2008).

32. E. Duguet, S. Vasseur, S. Mornet, J. M. Devoisselle, Magnetic Nanoparticles and Their Applications in Medicine, Nanomed. 1, 157-168 (2006).

33. S. M. Moghimi, A. C. Hunter, J. C. Murray, Long-Circulating and Target-Specific Nanoparticles: Theory to Practice, Pharmacol. Rev. 53, 283-318 (2001).

34. C. Corot, P. Robert, J. M. Idee, M. Port, Recent Advances in Iron Oxide Nanocrystal Technology for Medical Imaging, Adv. Drug Deliv. Rev. 58, 1471-1504 (2006). 
35. A. C. Faure, S. Dufort, V. Josserand, P. Perriat, J. L. Coll, S. Roux, O. Tillement, Control of the in Vivo Biodistribution of Hybrid Nanoparticles with Different Poly(ethylene Glycol) Coatings, Small 5, 2565-2575 (2009).

36. G. Ge, H. Wu, F. Xiong, Y. Zhang, Z. Guo, Z. Bian, J. Xu, C. Gu, N. Gu, X. Chen, D. Yang, The Cytotoxicity Evaluation of Magnetic Iron Oxide Nanoparticles on Human Aortic Endothelial Cells, Nanoscale Res. Lett. 8, 215 (2013).

37. C. Barrera, A. P. Herrera, C. Rinaldi, Colloidal Dispersions of Monodisperse Magnetite Nanoparticles Modified with Poly(ethylene Glycol), J. Colloid Interface Sci. 329, 107113 (2009).

38. C. Oh, Y. G. Lee, T. S. Choi, C. U. Jon, S. G. Oh, Facile Synthesis of PEG-Silica Hybrid Particles Using One-Step Sol-Gel Reaction in Aqueous Solution, Colloids Surf. Physicochem. Eng. Asp. 349, 145-150 (2009).

39. F. Bertorelle, C. Wilhelm, J. Roger, F. Gazeau, C. Menager, V. Cabuil, FluorescenceModified Superparamagnetic Nanoparticles: Intracellular Uptake and Use in Cellular Imaging, Langmuir 22, 5385-5391 (2006).

40. L. Maurizi, H. Bisht, F. Bouyer, N. Millot, Easy Route to Functionalize Iron Oxide Nanoparticles via Long-Term Stable Thiol Groups, Langmuir 25, 8857-8859 (2009).

41. R. Massart, E. Dubois, V. Cabuil, E. Hasmonay, Preparation and Properties of Monodisperse Magnetic Fluids, J. Magn. Magn. Mater. 149, 1-5 (1995).

42. J. Boudon, J. Paris, Y. Bernhard, E. Popova, R. A. Decreau, N. Millot, Magneto-Optical Nanomaterial: A SPIO-Phthalocyanine Scaffold Built Step-by-Step towards Bimodal Imaging, Chem. Commun. 49, 7394-7396 (2013).

43. S. Jo, K. Park, Surface Modification Using Silanated Poly(ethylene Glycol)s, Biomaterials 21, 605-616 (2000).

44. C. Flesch, M. Joubert, E. Bourgeat-Lami, S. Mornet, E. Duguet, C. Delaite, P. Dumas, Organosilane-Modified Maghemite Nanoparticles and Their Use as Co-Initiator in the Ring-Opening Polymerization of Epsilon-Caprolactone, Colloids Surf. -Physicochem. Eng. Asp. 262, 150-157 (2005).

45. R. Shen, P. H. C. Camargo, Y. Xia, H. Yang, Silane-Based Poly(ethylene Glycol) as a Primer for Surface Modification of Nonhydrolytically Synthesized Nanoparticles Using the Stober Method, Langmuir 24, 11189-11195 (2008).

46. P. Eyer, F. Worek, D. Kiderlen, G. Sinko, A. Stuglin, V. Simeon-Rudolf, E. Reiner, Molar Absorption Coefficients for the Reduced Ellman Reagent: Reassessment, Anal. Biochem. 312, 224-227 (2003).

47. A.-L. Papa, L. Maurizi, D. Vandroux, P. Walker, N. Millot, Synthesis of Titanate Nanotubes Directly Coated with USPIO in Hydrothermal Conditions: A New Detectable Nanocarrier, J. Phys. Chem. C 115, 19012-19017 (2011).

48. K. H. Diehl, R. Hull, D. Morton, R. Pfister, Y. Rabemampianina, D. Smith, J. M. Vidal, C. van de Vorstenbosch, European Federation of Pharmaceutical Industries Association and European Centre for the Validation of Alternative Methods, A Good Practice Guide to the Administration of Substances and Removal of Blood, Including Routes and Volumes, J. Appl. Toxicol. JAT 21, 15-23 (2001).

49. D. W. Yang, Q. Ye, M. Williams, Y. Sun, T. C. C. Hu, D. S. Williams, J. M. F. Moura, C. Ho, USPIO-Enhanced Dynamic MRI: Evaluation of Normal and Transplanted Rat Kidneys, Magn. Reson. Med. 46, 1152-1163 (2001).

50. D. E. Sosnovik, M. Nahrendorf, R. Weissleder, Magnetic Nanoparticles for MR Imaging: Agents, Techniques and Cardiovascular Applications, Basic Res. Cardiol. 103, 122-130 (2008).

51. N. Fauconnier, A. Bee, J. Roger, J. N. Pons, Synthesis of Aqueous Magnetic Liquids by Surface Complexation of Maghemite Nanoparticles, J. Mol. Liq. 83, 233-242 (1999). 
52. Y. W. Jun, Y. M. Huh, J. S. Choi, J. H. Lee, H. T. Song, S. Kim, S. Yoon, K. S. Kim, J. S. Shin, J. S. Suh, J. Cheon, Nanoscale Size Effect of Magnetic Nanocrystals and Their Utilization for Cancer Diagnosis via Magnetic Resonance Imaging, J. Am. Chem. Soc. 127, 5732-5733 (2005).

53. Y. W. Jun, J. W. Seo, A. Cheon, Nanoscaling Laws of Magnetic Nanoparticles and Their Applicabilities in Biomedical Sciences, Acc. Chem. Res. 41, 179-189 (2008).

54. B. A. Larsen, M. A. Haag, N. J. Serkova, K. R. Shroyer, C. R. Stoldt, Controlled Aggregation of Superparamagnetic Iron Oxide Nanoparticles for the Development of Molecular Magnetic Resonance Imaging Probes, Nanotechnology 19 (2008).

55. A. Roch, Y. Gossuin, R. N. Muller, P. Gillis, Superparamagnetic Colloid Suspensions: Water Magnetic Relaxation and Clustering, J. Magn. Magn. Mater. 293, 532-539 (2005).

56. L. E. W. LaConte, N. Nitin, O. Zurkiya, D. Caruntu, C. J. O'Connor, X. P. Hu, G. Bao, Coating Thickness of Magnetic Iron Oxide Nanoparticles Affects R2 Relaxivity, J. Magn. Reson. Imaging 26, 1634-1641 (2007).

57. T. Schlorf, M. Meincke, E. Kossel, C.-C. Glüer, O. Jansen, R. Mentlein, Biological Properties of Iron Oxide Nanoparticles for Cellular and Molecular Magnetic Resonance Imaging, Int. J. Mol. Sci. 12, 12-23 (2010).

58. A. P. Khandhar, R. M. Ferguson, J. A. Simon, K. M. Krishnan, Tailored Magnetic Nanoparticles for Optimizing Magnetic Fluid Hyperthermia, J. Biomed. Mater. Res. A 100, 728-737 (2012).

59. A. P. Khandhar, R. M. Ferguson, H. Arami, K. M. Krishnan, Monodisperse Magnetite Nanoparticle Tracers for in Vivo Magnetic Particle Imaging, Biomaterials 34, 38373845 (2013).

60. M. F. Calmon, A. T. de Souza, N. M. Candido, M. I. B. Raposo, S. Taboga, P. Rahal, J. G. Nery, A Systematic Study of Transfection Efficiency and Cytotoxicity in HeLa Cells Using Iron Oxide Nanoparticles Prepared with Organic and Inorganic Bases, Colloids Surf. B Biointerfaces 100, 177-184 (2012).

61. M. Goutayer, S. Dufort, V. Josserand, A. Royere, E. Heinrich, F. Vinet, J. Bibette, J. L. Coll, I. Texier, Tumor Targeting of Functionalized Lipid Nanoparticles: Assessment by in Vivo Fluorescence Imaging, Eur. J. Pharm. Biopharm. 75, 137-147 (2010).

62. Y. Okuhata, Delivery of Diagnostic Agents for Magnetic Resonance Imaging, Adv. Drug Deliv. Rev. 37, 121-137 (1999).

63. S. Mornet, S. Vasseur, F. Grasset, P. Veverka, G. Goglio, A. Demourgues, J. Portier, E. Pollert, E. Duguet, Magnetic Nanoparticle Design for Medical Applications, Prog. Solid State Chem. 34, 237-247 (2006).

64. L. Maurizi, U. Sakulkhu, A. Gramoun, J.-P. Vallee, H. Hofmann, A Fast and Reproducible Method to Quantify Magnetic Nanoparticle Biodistribution, Analyst 139, 1184-1191 (2014). 


\section{Figures}

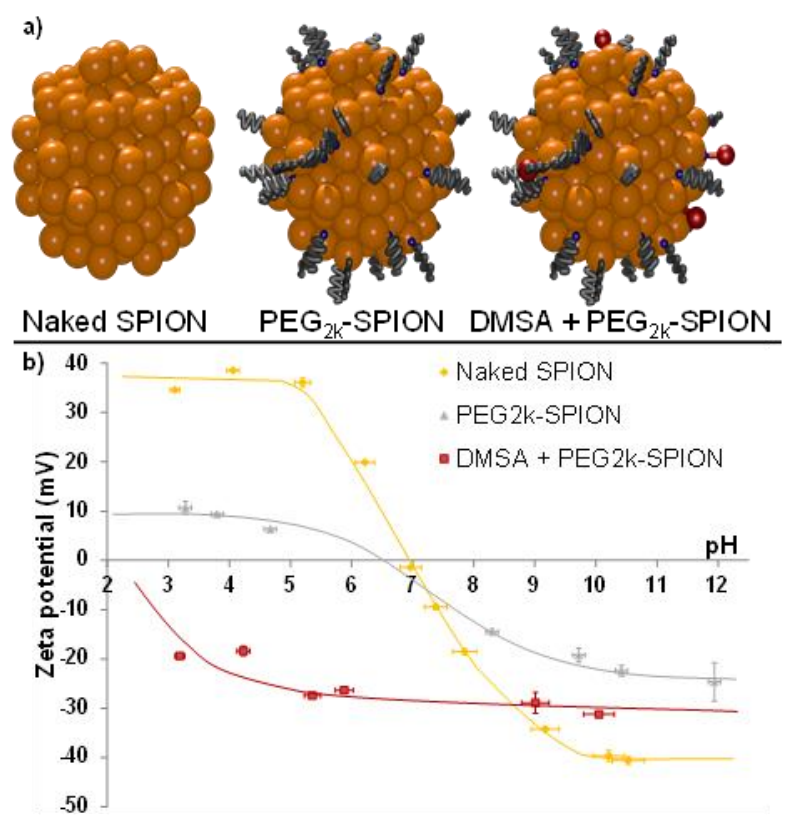

Figure 1: a) Representation of the three types of synthesized SPION (shown in orange). From left to right: naked SPION, SPION coated with PEG (shown in red); b) $\zeta$-potential at the indicated $\mathrm{pH}$ for the three types of SPION, measured in $10^{-2} \mathrm{M} \mathrm{NaCl}$ solution. 

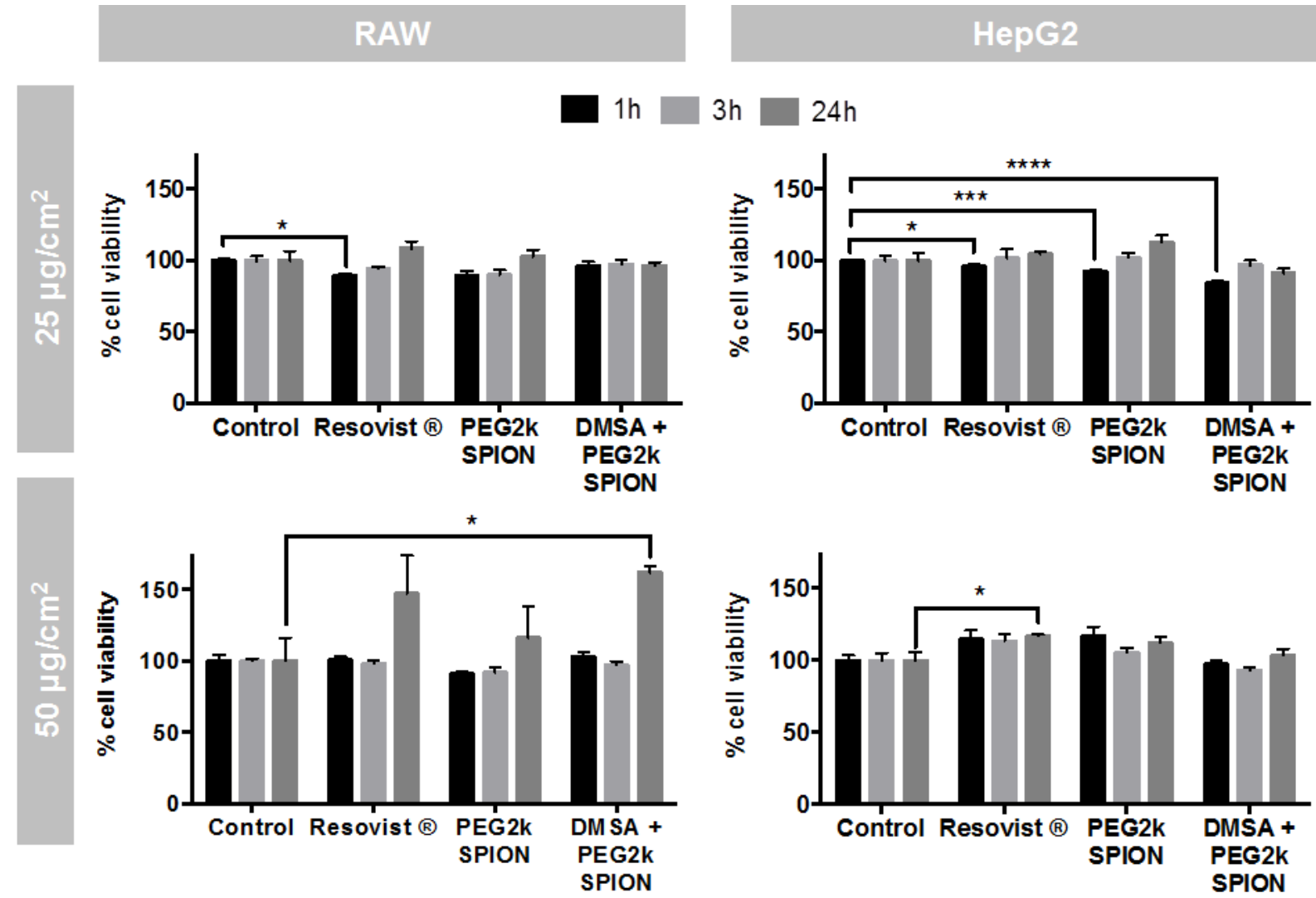

Figure 2: Cytotoxicity results from MTT assays performed on RAW 264.7 and HepG2 cells with Resovist ${ }^{\circledR}, \mathrm{PEG}_{2 \mathrm{k}}-\mathrm{SPION}$, and $\mathrm{PEG}_{2 \mathrm{k}}-\mathrm{SPION}+$ DMSA after 1-, 3-, and 24-h incubations. The results are given as a percentage of the control cells, incubated with medium only. Concentration used: 25 and $50 \mu \mathrm{g}_{\mathrm{Fe} . \mathrm{cm}^{-2}} \cdot{ }^{*} \mathrm{p} \leq 0.05, * * \mathrm{p} \leq 0.01, * * * \mathrm{p} \leq 0.001$, ****p $\leq$ 0.001, for the comparison with control cells. 


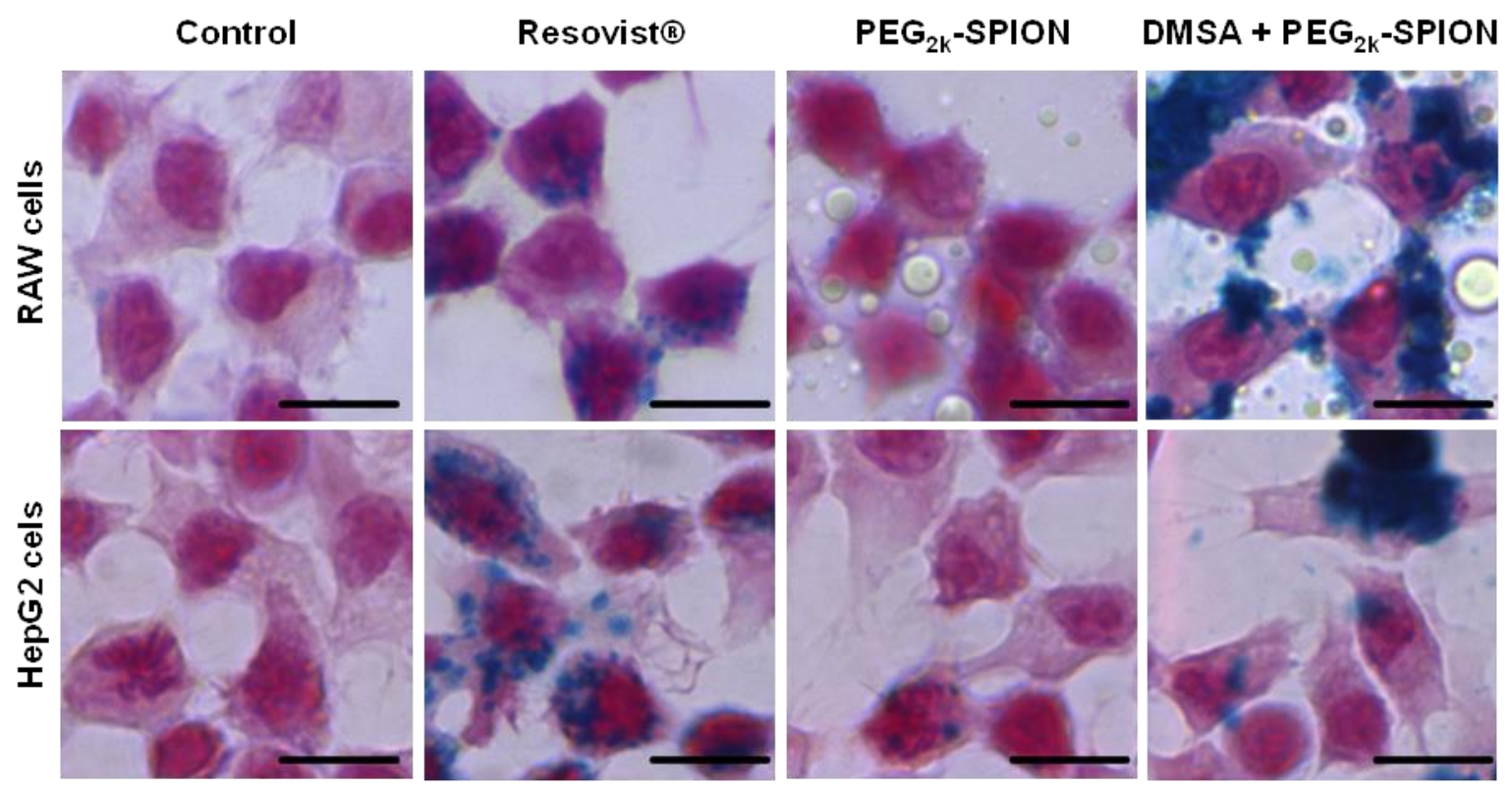

Figure 3: Representative optical microscope images of RAW 264.7 and HepG2 cells stained with Prussian blue after incubation with: complete medium (Control), Resovist $\AA, P_{2} G_{2 k}-S P I O N$, or DMSA + PEG $2 k-S P I O N$. Blue color represents the presence of iron from dissolved SPIONs. Concentration used: $25 \mu \mathrm{gFe}_{\mathrm{Fem}}{ }^{-2}$. Scale bar: 10 $\mu \mathrm{m}$. 

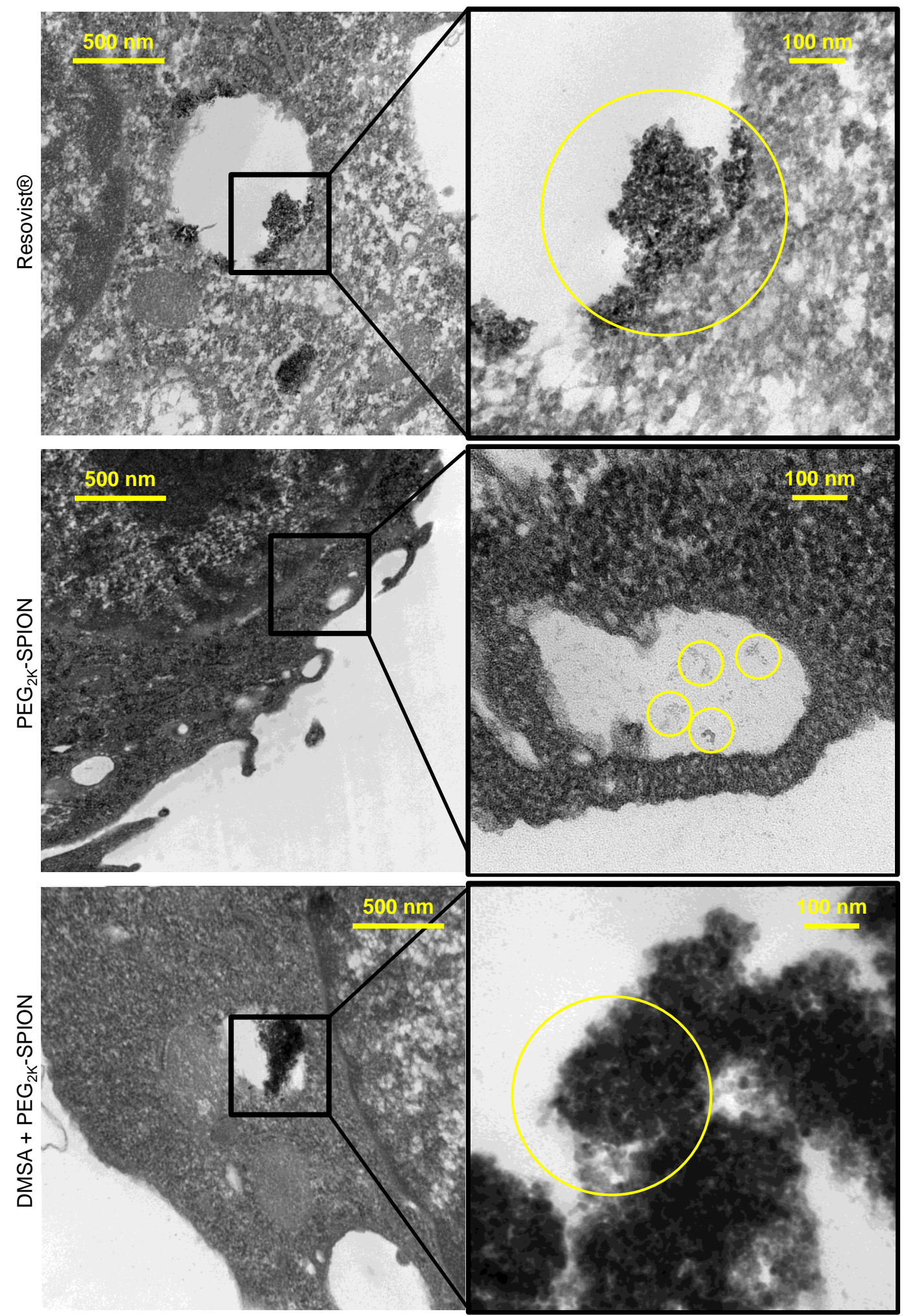

Figure 4: Representative Transmission Electron Microscope images of RAW 264.7 cells incubated with: Resovist $\Theta$, PEG $2 k-S P I O N$, or DMSA + PEG $2 k-S P I O N$, showing 2 magnifications per condition. The yellow-circled darkest points indicate the presence of SPIONs. Concentration used: $25 \mu \mathrm{g}_{\mathrm{Fe}} / \mathrm{cm}^{2}$. 
a)



b)

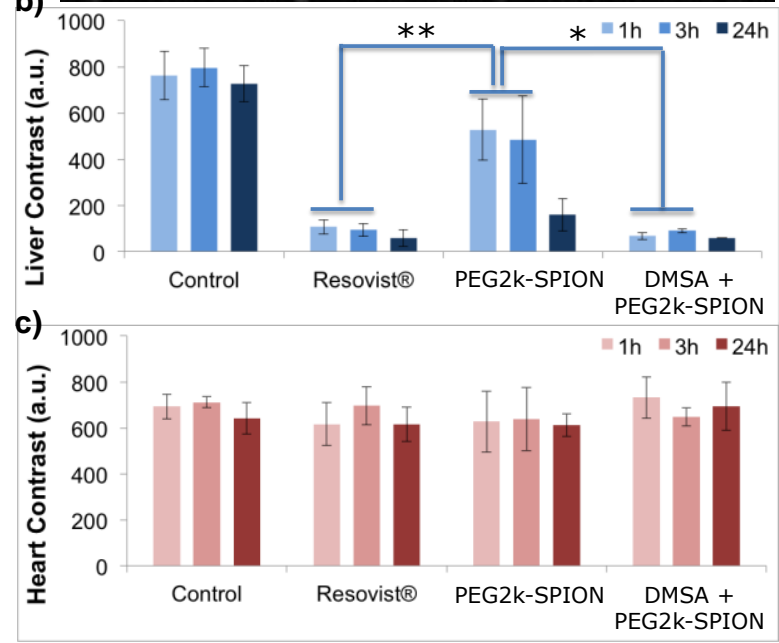

Figure 5: a) Coronal magnetic resonance images (MRI) of mice $3 \mathrm{~h}$ after injection of (from left to right): physiological saline (Control), Resovist ${ }^{\circledR}, \mathrm{PEG}_{2 k}-\mathrm{SPION}$, or DMSA + PEG ${ }_{2 k}$ SPION; b) Relative MRI contrasts measured in livers from mice injected with physiological saline (Control), Resovist@, PEG ${ }_{2 k}-S P I O N$, or DMSA + PEG ${ }_{2 k}$-SPION at 1, 3, and $24 \mathrm{~h}$ after injection; c) Relative MRI contrasts measured in hearts from mice injected with physiological saline (Control), Resovist ${ }^{\circledR}, \mathrm{PEG}_{2 \mathrm{k}}-\mathrm{SPION}$, or DMSA $+\mathrm{PEG}_{2 \mathrm{k}}-\mathrm{SPION}$ at 1,3 , and $24 \mathrm{~h}$ after injection. The red line in part a) surrounds the liver. Concentration used: $5.6 \mathrm{mgFe}^{-\mathrm{kg}^{-1}}$. MRI pictures at $\mathrm{T}_{\mathrm{E}}: 2.9 \mathrm{~ms}$, $T_{R}: 300 \mathrm{~ms}$, slice thickness: $2 \mathrm{~mm}$, resolution: $0.35 \mu \mathrm{m}^{2}$. Significances were reported as: ${ }^{*} p \leq 0.05,{ }^{* *} p \leq 0.01$. Administration of all SPIONs significantly altered the liver contrast, compared with the control, at all time-points. 




Figure 6: Representative optical microscope images of liver and heart slices stained with Prussian blue. Livers were obtained from mice injected with: physiological saline (Control), Resovist ${ }, \mathrm{PEG}_{2 \mathrm{k}}-\mathrm{SPION}$, or DMSA + $\mathrm{PEG}_{2 \mathrm{k}}$-SPION and sacrificed 3 and $24 \mathrm{~h}$ after injection. Hearts were obtained from mice injected with: physiological saline (Control), Resovist ${ }^{\circledR}, \mathrm{PEG}_{2 \mathrm{k}}-\mathrm{SPION}$, or DMSA + PEG $2 \mathrm{k}-\mathrm{SPION}$ and sacrificed $24 \mathrm{~h}$ after injection. Blue spots indicate the presence of iron from dissolved SPIONs. Concentration used: $5.6 \mathrm{mgFe}_{\mathrm{Fe}} \mathrm{kg}^{-1}$ mouse. Scale bar: $10 \mu \mathrm{m}$. 
Table 1: Physicochemical properties of Resovist®, naked SPIONs, SPIONs functionalized with PEG $\mathrm{B}_{2 k}$, and PEG + DMSA

\begin{tabular}{|c|c|c|c|c|c|c|}
\hline Nanoparticles & $\begin{array}{l}\mathbf{d}_{\mathrm{TEM}} \\
(\mathrm{nm})\end{array}$ & $\begin{array}{c}d_{H} \\
(n m)\end{array}$ & $\begin{array}{c}\xi \text { potential } \\
\text { at pH } 7(\mathrm{mV})\end{array}$ & $\begin{array}{l}\mathrm{S}_{\mathrm{BET}} \\
\mathrm{m}^{2} \cdot \mathrm{g}^{-1}\end{array}$ & Molec.nm-2 & $\begin{array}{l}\mathrm{r}_{2} \text { relaxivity } \\
\left(\mathrm{mM}^{-1} \mathrm{Fe}^{\left.-\mathrm{s}^{-1}\right)}\right.\end{array}$ \\
\hline Resovist® & $8 \pm 2$ & $22 \pm 4$ & $-22 \pm 2$ & n.d. & n.d. & $260 \pm 14$ \\
\hline Naked SPION & $9 \pm 3$ & $23 \pm 1$ & $0 \pm 3$ & 110 & 0 & $285 \pm 12$ \\
\hline $\mathrm{PEG}_{2 \mathrm{k}}-\mathrm{SPION}$ & $9 \pm 3$ & $38 \pm 5$ & $-3 \pm 3$ & 110 & 3.3 PEG & $260 \pm 9$ \\
\hline DMSA + PEG ${ }_{2 k}-S P I O N$ & $9 \pm 3$ & $36 \pm 4$ & $-30 \pm 3$ & 110 & $\begin{array}{c}0.6 \text { PEG } \\
0.3 \text { DMSA }\end{array}$ & $297 \pm 7$ \\
\hline
\end{tabular}

